\title{
Effect of pH and Oxygen on Growth and Viability of Acetivibrio cellulolyticus
}

\author{
By C. BREUIL AND G. B. PATEL* \\ Division of Biological Sciences, National Research Council of Canada, Ottawa, Ontario, \\ Canada K1A 0R6
}

(Received 23 September 1980; revised 16 December 1980)

\begin{abstract}
Growth, hydrogen production and cellulose digestion by Acetivibrio cellulolyticus strain CD2 were considerably greater when the culture $\mathrm{pH}$ was maintained at 7.0 than when the $\mathrm{pH}$ was not controlled. Furthermore, if the $\mathrm{pH}$ of the growth medium was controlled the number of viable organisms was 6 -fold greater after $3 \mathrm{~d}$ incubation and 100 -fold greater after $6 \mathrm{~d}$ incubation compared with equivalent cultures in which the $\mathrm{pH}$ was not controlled. The differences were due to the combined effect of low $\mathrm{pH}$ values and acetic acid accumulation. The number of viable organisms was 2 - to 3 -fold lower after $12 \mathrm{~h}$ incubation in substrate-free medium containing $40 \mathrm{~mm}$-acetic acid at $\mathrm{pH} 5.5$ than in the same medium at $\mathrm{pH} 7.0$. Addition of $90 \mathrm{~mm}$-acetic acid during growth in a cellobiose-containing medium lowered the growth rate by $30 \%$ and the rate of hydrogen production by $40 \%$. Exposure of $A$. cellulolyticus to oxygen for up to $2 \mathrm{~h}$ did not affect viability measurements provided that the organisms were subsequently transferred to reduced media.
\end{abstract}

\section{INTRODUCTION}

Acetivibrio cellulolyticus can grow on cellulose, cellobiose and salicin (Patel et al., 1980). As growth proceeds the $\mathrm{pH}$ of the growth medium drops from 7.0 to 5.5 (in the absence of $\mathrm{pH}$ control) due to the accumulation of acetic acid; this is one of the major metabolic end-products, others being $\mathrm{H}_{2}, \mathrm{CO}_{2}$, reducing sugars and ethanol (Khan et al., 1980; Patel et al., 1980). The aim of this study was to determine the effects of acetic acid accumulation and decreasing $\mathrm{pH}$ on the growth, viability and cellulose-degrading ability of $A$. cellulolyticus. As $A$. cellulolyticus is an obligate anaerobe which requires pre-reduced media for growth (Patel et al., 1980), an additional aim was to examine the effect of exposure to $\mathrm{O}_{2}$ on the viability of $A$. cellulolyticus.

\section{METHODS}

Bacterial strain and growth conditions. Acetivibrio cellulolyticus strain CD2 (National Research Council of Canada culture collection no. 2248, ATCC 33288) was maintained in $10 \mathrm{ml}$ basal medium (Patel et al., 1980) containing $30 \mathrm{mg}$ white facial tissue paper (Kleenex, Kimberly Clark Co., Canada), incubated at $35^{\circ} \mathrm{C}$ and subcultured at weekly intervals. The tissue was present as strips $(10 \times 35 \mathrm{~mm})$ in serum vials which were flushed with an $\mathrm{O}_{2}$-free gas mixture of $\mathrm{N}_{2} / \mathrm{CO}_{2}(80: 20, \mathrm{v} / \mathrm{v})$. Unless stated otherwise, all media preparation and growth experiments were conducted using this gas mixture. The basal medium was pre-reduced by the serum bottle modification (Miller \& Wolin, 1974) of the Hungate (1950) technique, using $8 \mathrm{ml} \mathrm{l}^{-1}$ of the cysteine/ $\mathrm{Na}_{2} \mathrm{~S}$ reducing solution $\left[1.25 \%(\mathrm{w} / \mathrm{v})\right.$ cysteine. $\mathrm{HCl}$ and $1.25 \%(\mathrm{w} / \mathrm{v}) \mathrm{Na}_{2} \mathrm{~S} .9 \mathrm{H}_{2} \mathrm{O}$ in distilled water (Holdeman \& Moore, 1975)]. Portions $(10 \mathrm{ml})$ of the reduced basal medium were dispensed into the serum vials containing the cellulose. The vials were sealed, autoclaved at $121^{\circ} \mathrm{C}$ for $15 \mathrm{~min}$, and then a further $0.08 \mathrm{ml}$ reducing solution was added to each vial. The initial $\mathrm{pH}$ was $7 \cdot 0 \pm 0 \cdot 2$.

For the experiments, culture vessels $(250 \mathrm{ml}$ or $500 \mathrm{ml}$ Erlenmeyer flasks with side arms) contained $100 \mathrm{ml}$ basal medium supplemented with $1 \mathrm{~g}$ facial tissue paper or $\mathrm{D}(+)$-cellobiose (Eastman Kodak) and were sealed with serum stoppers. The medium was pre-reduced by the addition of $1.5 \mathrm{ml}$ reducing solution per $100 \mathrm{ml}$ basal medium, 
$1.0 \mathrm{ml}$ of which was added before autoclaving and the remainder afterwards. Cellobiose was added to the autoclaved basal medium as a $10 \%(\mathrm{w} / \mathrm{v})$ filter-sterilized (Sartorius filter, $0.2 \mu \mathrm{m}$ average pore diameter) solution which was made anaerobic by addition of $1.5 \%(\mathrm{v} / \mathrm{v})$ reducing solution. To determine the effect of high acetic acid concentrations on growth and $\mathrm{H}_{2}$ production in media with the $\mathrm{pH}$ controlled at $7 \cdot 0$, acetic acid solutions adjusted to $\mathrm{pH} 7.0$ were added to the autoclaved basal medium to give initial concentrations of up to $90 \mathrm{~mm}$. All cultures were incubated at $35^{\circ} \mathrm{C}$ on a rotary shaker operating at $120 \mathrm{rev} . \mathrm{min}^{-1}$. The head space in the sealed flasks was flushed daily to minimize any possible toxic effects of accumulated $\mathrm{H}_{2}$. The inoculum consisted of $2 \%(\mathrm{v} / \mathrm{v})$ of a $72 \mathrm{~h}$ culture grown on cellulose or a $24 \mathrm{~h}$ culture grown on cellobiose (with growth pH controlled at 7.0), for cellulose and cellobiose test substrates, respectively. Where indicated, the $\mathrm{pH}$ value was maintained at 7.0 during growth by the addition of sterile, anaerobic $2.5 \mathrm{M}-\mathrm{NaOH}$ every 4 to $6 \mathrm{~h}$ during the growth period; the maximum deviation from $\mathrm{pH} 7 \cdot 0$ in these cultures was less than $0 \cdot 3$.

The combined effect of low $\mathrm{pH}(5 \cdot 5)$ and high acetic acid concentration $(40 \mathrm{mM})$ on viability was determined on exponential phase, cellobiose-grown cells. Cells were harvested from an exponentially growing culture $\left(A_{660} 0.75\right)$ by centrifuging $(16300 \mathrm{~g}, 15 \mathrm{~min})$ and resuspended in pre-reduced basal medium $(\mathrm{pH} 7.0)$ at 30 times the initial concentration. Then $1 \mathrm{ml}$ of the concentrated cell suspension was injected into sealed vials containing $29 \mathrm{ml}$ pre-reduced basal medium adjusted to $\mathrm{pH} 7.0$ or 5.5 and supplemented with 0,25 or $40 \mathrm{mM}$-acetic acid. The vials were incubated at $35^{\circ} \mathrm{C}$. (These tests were done on harvested organisms resuspended in substrate-free medium because the organism does not grow at $\mathrm{pH}$ values below 6.5.)

Measurement of growth and viability. Growth in cellobiose medium was followed by measuring the turbidity at $660 \mathrm{~nm}$ using a Spectronic 20 spectrophotometer (Bausch \& Lomb, Rochester, N.Y., U.S.A.). Viable cells were estimated by the most probable number (MPN) technique (Taras et al., 1976). The sample was serially diluted into pre-reduced basal medium and each dilution was inoculated into five replicate vials of cellulose or cellobiose medium. A positive result was assessed by visual observation of tissue paper digestion, by culture turbidity and microscopy. Statistical tables were used for the calculation of the MPN of viable cells in the original sample (Taras et al., 1976).

Estimation of cellulose degradation and the production of $\mathrm{H}_{2}$ and acetic acid. The cultures were centrifuged at $16300 \mathrm{~g}$ for $20 \mathrm{~min}$ and the pellet of cells and cellulose was extracted with an acetic acid/nitric acid reagent (Sloneker, 1971). This extraction disrupted the cells and solubilized protein, lipid, lignin and hemicellulose (which were discarded in the supernate), leaving the cellulose fibres intact. The cellulose pellet which remained after extraction was dissolved in $75 \%(\mathrm{w} / \mathrm{v}) \mathrm{H}_{2} \mathrm{SO}_{4}$ and carbohydrate was estimated by the anthrone reagent (Herbert et al., 1971) using Whatman CF11 cellulose powder as a standard. When $10 \mathrm{~g}$ facial tissue paper was extracted as above, $8 \mathrm{~g}$ was recovered as cellulose; this was taken to be the initial cellulose concentration in Fig. $1(\mathrm{~b})$.

After a period of growth, the gas pressure in the sealed flasks was equilibrated to atmospheric pressure by releasing the gas into a $100 \mathrm{ml}$ burette filled with water, and the $\mathrm{H}_{2}$ content was assayed by gas chromatography (Van Huyssteen, 1967). Acetic acid in the medium was assayed as described by Ackman (1972).

Determination of oxygen tolerance. A $60 \mathrm{~h}$ culture in cellulose medium $(100 \mathrm{ml})$ was transferred to a sterile 11 Erlenmeyer flask plugged with sterile cotton. The culture was incubated at $25^{\circ} \mathrm{C}$ and aerated by means of a magnetic stirrer (150 rev. $\min ^{-1}$ ). At $0,2,5$ and $24 \mathrm{~h}, 7 \mathrm{ml}$ samples were aseptically removed. Part of each sample (2 ml) was flushed with $\mathrm{N}_{2} / \mathrm{CO}_{2}(80: 20$, v/v) and serially diluted for the determination of the numbers of viable cells. Dissolved $\mathrm{O}_{2}$ and redox potential were determined on the remaining $5 \mathrm{ml}$ of each sample. The dissolved $\mathrm{O}_{2}$ was measured with a polarographic oxygen probe (Beckman 39065) and monitored with a Beckman model 777 laboratory oxygen analyser. The oxygen probe was standardized with atmospheric $\mathrm{O}_{2}$ and with distilled water saturated with atmospheric $\mathrm{O}_{2}$. The redox potential $\left(E_{\mathrm{h}}\right)$ was measured using a platinum/calomel electrode (PK149, Radiometer) and a pH meter (PHM26, Radiometer).

All tests were conducted in duplicate and were repeated at least twice. Typical results are presented.

\section{RESULTS AND DISCUSSION}

A lag period of about $1 \mathrm{~d}$ was observed (Fig. $1 a, b$ ) when an actively growing culture of $A$. cellulolyticus was transferred to fresh medium. This was initially thought to be due to a low cellulolytic activity because of the small inoculum size $(2 \%, v / v)$. However, increasing the inoculum size to $10 \%(\mathrm{v} / \mathrm{v})$ did not appreciably decrease the lag period. After $1 \mathrm{~d}$ incubation, $\mathrm{H}_{2}$ production (Fig. $1 \mathrm{a}$ ) and cellulose degradation (Fig. $1 \mathrm{~b}$ ) began concurrently. Between 1 and $3 \mathrm{~d}$ of incubation about $60 \%$ of the cellulose initially available $\left(8 \mathrm{~g} \mathrm{I}^{-1}\right)$ was digested. In the absence of $\mathrm{pH}$ control, the $\mathrm{pH}$ decreased from 7.0 to between 6.0 and 5.5 during this period; the lower value was at least $0.5 \mathrm{pH}$ units below the minimum growth $\mathrm{pH}(6.5)$ for $A$. cellulolyticus (Patel et al., 1980). The $\mathrm{pH}$ finally reached $\mathrm{pH} 5.5$, a value which is close to the 

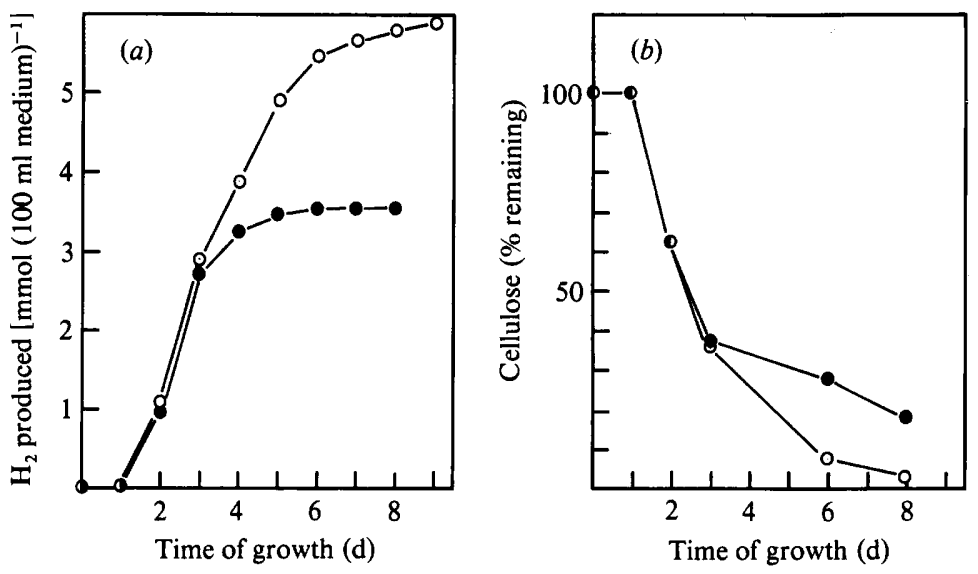

Fig. 1. Growth of $A$. cellulolyticus in medium containing cellulose with the pH maintained at $7.0(0)$ and with the $\mathrm{pH}$ not controlled $(\mathrm{O})$ : $(a)$ cumulative $\mathrm{H}_{2}$ production; $(b)$ percentage of cellulose remaining.

optimum for cellulase activity of this organism (Saddler \& Khan, 1980). About $20 \%$ of the cellulose initially available remained undegraded after $8 \mathrm{~d}$ incubation in the absence of $\mathrm{pH}$ control. However, in cultures controlled at $\mathrm{pH} 7.0$ during growth, most of the substrate was degraded after $8 \mathrm{~d}$ and approximately $70 \%$ more $_{2}$ was produced (Fig. $1 a, b$ ). These results indicated that for complete degradation of cellulose the $\mathrm{pH}$ must be maintained at 7.0 to maximize growth, even though this is higher than the optimum $\mathrm{pH}$ for cellulase activity.

Increasing the ratio of the volume of the growth medium to that of the culture vessel gas phase from $1: 2$ to $1: 4$ resulted in the production of about $15 \%$ more $\mathrm{H}_{2}$ than that shown in Fig. 1 (a), probably due to the reduction of the partial pressure of $\mathbf{H}_{2}$ in the larger volume gas phase. Cellulose degradation was not affected. High $\mathrm{H}_{2}$ concentrations are known to inhibit $\mathrm{H}_{2}$ production by some anaerobes (Zajic et al., 1978). Our observations during cultivation (500 ml flasks) in cellobiose medium (with growth $\mathrm{pH}$ controlled) indicated that about $15 \%$ $\mathrm{H}_{2}$ accumulated in the gas phase after $24 \mathrm{~h}$ incubation if the head space was not flushed with $\mathrm{N}_{2} / \mathrm{CO}_{2}(80: 20, \mathrm{v} / \mathrm{v})$ every $12 \mathrm{~h}$. Although the growth $\left(A_{660} 1.0\right)$ and cumulative $\mathrm{H}_{2}$ produced [ $5 \mathrm{mmol}(100 \mathrm{ml} \text { medium })^{-1}$ ] after $24 \mathrm{~h}$ incubation were similar to those for cultures in which the head space was flushed every $12 \mathrm{~h}$, the cumulative $\mathrm{H}_{2}$ production after $36 \mathrm{~h}$ incubation $(6.38 \mathrm{mmol})$ was $15 \%$ lower than that for cultures in which the head space was flushed. Since the other growth conditions were identical, the inhibition of $\mathrm{H}_{2}$ production observed between 24 and $36 \mathrm{~h}$ of incubation was most likely due to the $>15 \% \mathrm{H}_{2}$ accumulation in the gas phase.

The viability of $A$. cellulolyticus growing on cellulose (Table 1) could not be ascertained accurately before $2 \mathrm{~d}$ incubation since the cells could not be quantitatively dislodged from the insoluble substrate to which they were attached. The zero-time viability was calculated from the viability of the inoculum. The maximum number of viable cells was observed after $3 \mathrm{~d}$ incubation (Table 1). At this time the viability of $\mathrm{pH}$-controlled cultures was about six times greater than that of cultures with no $\mathrm{pH}$ control. Irrespective of the growth conditions, there was a 15- to 25 -fold decrease in the number of viable organisms between 3 and $4 \mathrm{~d}$ of incubation. However, for cultures with no $\mathrm{pH}$ control, the number of viable cells declined more rapidly after $4 \mathrm{~d}$, leaving few viable organisms after $10 \mathrm{~d}$. With the growth $\mathrm{pH}$ maintained at 7.0, no decrease in viability occurred between 5 and $7 \mathrm{~d}$ and, although this culture accumulated $60 \%$ more acetic acid (Table 1), there were $10^{5}$ times more viable organisms per unit volume of culture than in the culture with no $\mathrm{pH}$ control. The results 
Table 1. Effect of $p H$ on viability and acetic acid production by $A$. cellulolyticus during growth on cellulose

Incubation
time
(d)
0
3
4
5
6
7
10

\begin{tabular}{cc} 
No. of viable organisms $\mathrm{ml}^{-1}$ \\
\hline $2.0 \times 10^{6}$ & $\mathrm{pH} \mathrm{control}$ \\
$4.3 \times 10^{8}$ & $2.0 \times 10^{6}$ \\
$2.4 \times 10^{7}$ & $9.3 \times 10^{9}$ \\
$2.4 \times 10^{6}$ & $2.4 \times 10^{7}$ \\
$2.4 \times 10^{5}$ & $2.4 \times 10^{7}$ \\
ND & $2.4 \times 10^{7}$ \\
$<1.0 \times 10^{1}$ & $2.3 \times 10^{6}$
\end{tabular}

$\overbrace{\text { No pH control }}^{\text {Acetic acid produced }(\mathrm{mM})}$

ND, Not determined.

indicated that maintaining the growth $\mathrm{pH}$ at 7.0 not only enabled complete substrate breakdown but also maintained a higher cell viability.

Acetic acid is toxic to some micro-organisms (Hentges, 1967; Stewart, 1975) and it accumulates in anaerobic digesters operating under non-optimal conditions (McCarty, 1964). The inhibitory effect of volatile fatty acids is due to the undissociated form (Hentges, 1967; Meynell, 1963). In the $\mathrm{pH}$ range 6.0 to 7.5 volatile fatty acids are almost completely dissociated (Capri \& Marais, 1975). At pH 5.5 and 7.0 the amount of acetic acid ( $K_{\mathrm{a}} 4.75$ ) in the undissociated form is $15.1 \%$ and $0.6 \%$, respectively. Thus, in cultures with no $\mathrm{pH}$ control, the concentration of undissociated acid after $3 \mathrm{~d}$ incubation $(\mathrm{pH} 5.5)$ would be $2.3 \mathrm{~mm}$ compared with only $0.1 \mathrm{~mm}$ in cultures grown at $\mathrm{pH} 7 \cdot 0$. Therefore, the $10^{7}$-fold decrease in viable organisms in the cultures without $\mathrm{pH}$ control, compared with the $10^{3}$-fold decrease in cultures with $\mathrm{pH}$ control, was probably due to the greater accumulation of the undissociated form of acetic acid.

To substantiate the above hypothesis, the combined effect of acetic acid and low $\mathrm{pH}$ on the viability of cellobiose-grown organisms was studied. Exponentially growing organisms were harvested and resuspended to the same density as in the original culture in substrate-free media containing 0 to $40 \mathrm{~mm}$-acetic acid at $\mathrm{pH} 5 \cdot 5$ or $7 \cdot 0$. This acetic acid range was chosen since it corresponded to the concentrations ( 40 and $25 \mathrm{~mm}$ ) which accumulated in cultures with or without $\mathrm{pH}$ control (Table 1). The two different $\mathrm{pH}$ values were chosen so that the amount of undissociated acetic acid in the medium would be altered. The results showed that in the absence of acetic acid, there was little or no loss of viability after $12 \mathrm{~h}$ incubation at pH 7.0 or 5.5 (Table 2). However, at pH 5.5 with 25 or 40 mM-acetic acid, there was about a 4 -fold decrease in viability. This decline was more pronounced after $24 \mathrm{~h}$ incubation with decreases of about $10^{4}$-fold. These results indicated that at acetic acid concentrations of 25 to $40 \mathrm{mM}$, the decline in cell viability was largely due to the expected greater concentration $(3.8$ to $6.0 \mathrm{~mm})$ of the undissociated form of acetic acid at $\mathrm{pH} 5.5$ than that $(0.2 \mathrm{mM})$ in $40 \mathrm{~mm}$-acetic acid at $\mathrm{pH} 7 \cdot 0$.

The effect of acetic acid on growth and $\mathrm{H}_{2}$ production during growth on cellobiose was investigated using initial acetic acid concentrations of $0,20,40$ and $90 \mathrm{~mm}$ and maintaining the growth $\mathrm{pH}$ at 7.0. Acetic acid at a concentration of $20 \mathrm{mM}$ did not affect $\mathrm{H}_{2}$ production or growth. However, with $40 \mathrm{~mm}$-acetic acid, $\mathrm{H}_{2}$ production was about $20 \%$ lower (Fig. 2 a) although the growth was similar to that in cultures with no added acetic acid (Fig. $2 b$ ). Both $\mathrm{H}_{2}$ production and growth were substantially lower (40\% and $30 \%$, respectively) with $90 \mathrm{~mm}$-acetic acid. With the initial acetic acid concentrations of $0,20,40$ and $90 \mathrm{~mm}$, the acetic acid concentrations after $82 \mathrm{~h}$ incubation had increased by $40.0,39.4,32.0$ and $28.4 \mathrm{~mm}$, respectively. Therefore, acetic acid production was inhibited by an initial acetic acid concentration which was greater than $20 \mathrm{mM}$. The results also demonstrated that at initial acetic acid concentrations above $40 \mathrm{mM}$, growth was adversely affected, even though the 
Table 2. Effect of $p H$ and acetic acid on the viability of $A$. cellulolyticus cells obtained from a culture in the exponential phase of growth on cellobiose

\begin{tabular}{|c|c|}
\hline & $\begin{array}{r}\text { cubation } \\
\text { nditions }\end{array}$ \\
\hline $\mathrm{pH}$ & $\begin{array}{l}\text { Acetic acid } \\
\text { concn (mM) }\end{array}$ \\
\hline $\begin{array}{l}7 \cdot 0 \\
5 \cdot 5\end{array}$ & $\begin{array}{l}0.0 \\
0.0\end{array}$ \\
\hline $5 \cdot 5$ & $25 \cdot 0$ \\
\hline $\begin{array}{l}7 \cdot 0 \\
5 \cdot 5\end{array}$ & $\begin{array}{l}40 \cdot 0 \\
40 \cdot 0\end{array}$ \\
\hline
\end{tabular}

\begin{tabular}{|c|c|c|}
\hline \multicolumn{3}{|c|}{ No. of viable organisms $\mathrm{ml}^{-1}$} \\
\hline $0 \mathrm{~h}$ & $\begin{array}{c}\text { Incubation time: } \\
12 \mathrm{~h}\end{array}$ & $24 \mathrm{~h}$ \\
\hline $\begin{array}{l}1.30 \times 10^{9} \\
1.30 \times 10^{9}\end{array}$ & $\begin{array}{l}1.09 \times 10^{9} \\
1.30 \times 10^{9}\end{array}$ & $\begin{array}{l}5.40 \times 10^{7} \\
1.60 \times 10^{7}\end{array}$ \\
\hline $1.30 \times 10^{9}$ & $0.35 \times 10^{9}$ & $6.30 \times 10^{5}$ \\
\hline $\begin{array}{l}1.30 \times 10^{9} \\
1.30 \times 10^{9}\end{array}$ & $\begin{array}{l}1.09 \times 10^{9} \\
0.35 \times 10^{9}\end{array}$ & $\begin{array}{l}3.48 \times 10^{7} \\
3.30 \times 10^{5}\end{array}$ \\
\hline
\end{tabular}
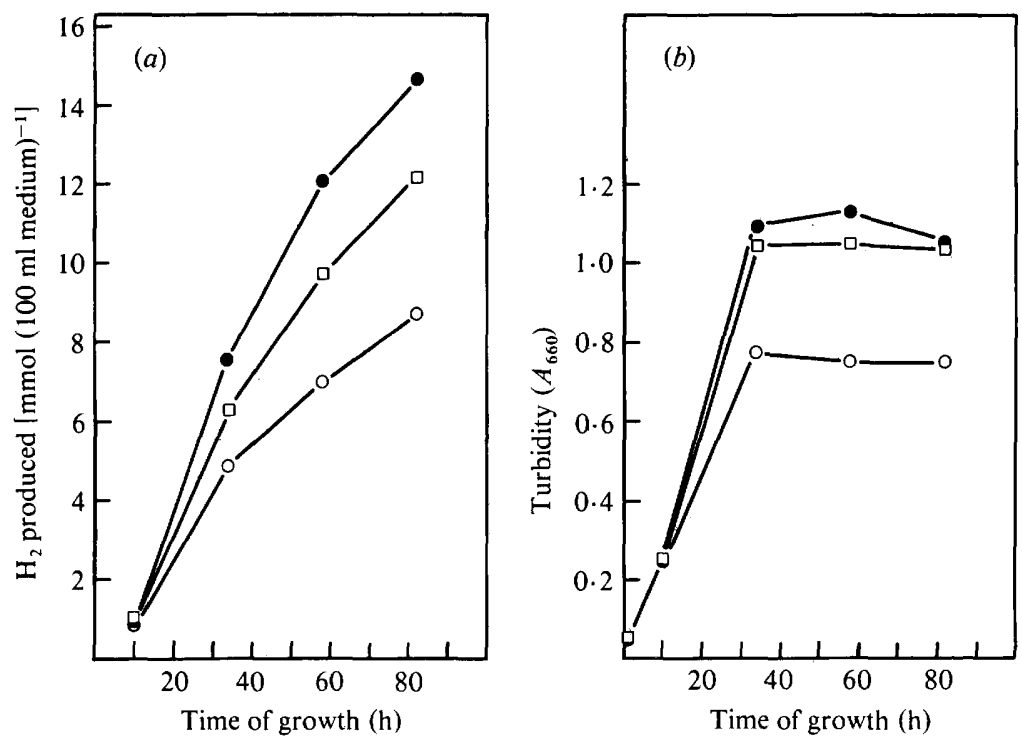

Fig. 2. Growth of $A$. cellulolyticus on medium containing cellobiose in the presence of acetic acid at initial concentrations of $0(\Theta), 40 \mathrm{~mm}(\square)$ and $90 \mathrm{mM}(O)$ with the $\mathrm{pH}$ of the medium maintained at 7.0: (a) cumulative $\mathrm{H}_{2}$ production; (b) growth.

Table 3. Viability of A. cellulolyticus culture after exposure to oxygen

$\begin{array}{cccc}\begin{array}{c}\text { Time of exposure } \\ (\mathrm{h})\end{array} & \begin{array}{c}E_{\mathrm{h}} \text { of medium } \\ (\mathrm{m} \mathrm{V})\end{array} & \begin{array}{c}\text { Partial pressure } \\ \text { of } \mathrm{O}_{2}(\mathrm{mmHg})\end{array} & \begin{array}{c}\text { No. of viable organisms } \\ \mathrm{ml}^{-1}\end{array} \\ 0 & -300 & - & 2.40 \times 10^{8} \\ 2 & +220 & 110 & 2.40 \times 10^{8} \\ 5 & +230 & 110 & 4.30 \times 10^{7} \\ 24 & +290 & 130 & 1.50 \times 10^{6}\end{array}$

growth $\mathrm{pH}$ was maintained at $7 \cdot 0$. Under normal cultivation conditions the maximum acetic acid accumulation during growth of $A$. cellulolyticus in $1 \%(\mathrm{w} / \mathrm{v})$ carbohydrate media did not exceed $40 \mathrm{~mm}$. Therefore, the inhibition of growth due to acetic acid accumulation is less likely to occur under normal circumstances, as long as the growth $\mathrm{pH}$ is maintained at 7.0.

The effect of $\mathrm{O}_{2}$ on the viability of $A$. cellulolyticus cells (Table 3 ) obtained from an exponentially growing culture indicated that the cells could tolerate up to $2 \mathrm{~h}$ exposure to $\mathrm{O}_{2}$ 
without measurable loss in viability-provided that they were subsequently transferred to pre-reduced media. After $5 \mathrm{~h}$ contact with $\mathrm{O}_{2}$, only $18 \%$ of the cells were able to grow. Although $A$. cellulolyticus is an obligate anaerobe which requires pre-reduced media for growth, the viability appeared to be relatively unaffected by short periods of exposure to $\mathrm{O}_{2}$. In this respect $A$. cellulolyticus did not differ from some other anaerobic bacteria belonging to the genera Bacteroides, Peptostreptococcus and Clostridium (Carlsson et al., 1977; Tally et al., 1975). The tolerance to $\mathrm{O}_{2}$ could, as demonstrated for other anaerobes, be due to the capacity of the cells to reduce $\mathrm{O}_{2}$ and/or due to detoxification of $\mathrm{O}_{2}$ through activities of enzymes like peroxidase and superoxide dismutase (Morris, 1976; Rolfe et al., 1978; Wimpenny \& Samah, 1978). In the present study, no attempt was made to determine the presence of specific defence mechanisms of $A$. cellulolyticus against $\mathrm{O}_{2}$ toxicity. The results indicated that it is possible to harvest the cells aerobically and resuspend them in anaerobic conditions without loss of viability.

The results of the present study indicate that acetic acid accumulation in conjunction with low $\mathrm{pH}$ values lowers cell viability and that $A$. cellulolyticus has a high tolerance to exposure to $\mathrm{O}_{2}$.

The authors acknowledge the capable technical assistance of Mr B. J. Agnew, Ms Sherril Carson and Ms Susan Porter. This paper is NRCC no. 19167.

\section{REFERENCES}

Ackman, R. G. (1972). Porous polymer bead packings and formic acid vapour in the GLC of volatile free fatty acids. Journal of Chromatographic Science 10, $560-565$.

CAPRI, M. G. \& MARAIS, G. V. (1975). pH adjustment in anaerobic digestion. Water Research 9, 307-313.

Carlsson, J., Frölander, F. \& Sundquist, G. (1977). Oxygen tolerance of anaerobic bacteria isolated from necrotic dental pulps. Acta odontologica scandinavica 35, 139-145.

HentGes, D. J. (1967). Influence of $\mathrm{pH}$ on the inhibitory activity of formic and acetic acids for Shigella. Journal of Bacteriology 93, 2029-2030.

Herbert, D., Phipps, P. J. \& Strange, R. E. (1971). Chemical analysis of microbial cells. Methods in Microbiology 5B, 209-344.

Holdeman, L. V. \& Moore, W. E. C. (1975). Anaerobe Laboratory Manual, 3rd edn. Blacksburg, Virginia: Virginia Polytechnic Institute \& State University.

Hungate, R. E. (1950). The anaerobic mesophilic cellulolytic bacteria. Bacteriological Reviews 14, $1-49$.

Khan, A. W., Saddler, J. N., Patel, G. B., Colvin, J. R. \& MARTIN, S. M. (1980). Degradation of cellulose by a newly isolated mesophilic anaerobe, Bacteroidaceae family. FEMS Microbiology Letters, 7, 47-50.

MCCARTY, P. L. (1964). Anaerobic waste treatment fundamentals I. Chemistry and microbiology. Public Works 95, 107-112.

MeyNELL, G. G. (1963). Antibacterial mechanisms of the mouse gut. II. The role of $E_{h}$ and volatile fatty acids in the normal gut. British Journal of Experimental Pathology 84, 379-382.

Miller, T. L. \& Wolin, M. J. (1974). A serum bottle modification of the Hungate technique for cultivating obligate anaerobes. Applied Microbiology 27, 985987.

Morris, J. G. (1976). Fifth Stenhouse Williams Memorial Lecture. Oxygen and the obligate anaerobe. Journal of Applied Bacteriology 40, 229-244.

Patel, G. B., Khan, A. W., Agnew, B. J. \& Colvin, J. R. (1980). Isolation and characterization of an anaerobic, cellulolytic microorganism, Acetivibrio cellulolyticus gen. nov., sp. nov. International Journal of Systematic Bacteriology 30, 179-185.

Rolfe, R. D., Hentges, D. J., CAMpbell, B. J. \& BARETT, J. T. (1978). Factors related to the oxygen tolerance of anaerobic bacteria. Applied and Environmental Microbiology 36, 306-313.

SAdDler, J. N. \& KHAN, A. W. (1980). Cellulase production by Acetivibrio cellulolyticus. Canadian Journal of Microbiology 26, 760-765.

SLONEKER, J. H. (1971). Determination of cellulose and apparent hemicellulose in plant tissue by gas-liquid chromatography. Analytical Biochemistry 43, 539-546.

StewarT, C. S. (1975). Some effects of phosphate and volatile fatty acid salts on the growth of rumen bacteria. Journal of General Microbiology 89, 319-326.

Tally, F. P., Stewart, P. R., Sutter, V. L. \& RosenblatT, J. E. (1975). Oxygen tolerance of fresh clinical anaerobic bacteria. Journal of Clinical Microbiology 1, 161-164.

Taras, M. J., Greenberg, A. E., Hoak, R. D. \& RAND, M. C. (editors) (1976). Standard Methods for the Examination of Water and Wastewater, 14th edn. Washington, D.C.: American Public Health Association-Water Pollution Control Federation.

Van Huyssteen, J. J. (1967). Gas chromatographic separation of digestor gases using porous polymers. Water Research 1, 237-242.

WimpenNy, J. W. T. \& SAMAH, O. A. (1978). Some effects of oxygen on the growth and physiology of Selenomonas ruminantium. Journal of General Microbiology 108, 329-332.

ZaJiC, J. E., Kosaric, N. \& Brosseau, J. D. (1978). Microbial production of hydrogen. Advances in Biochemical Engineering 9, 57-109. 